\title{
Introduction to Marylee Hardenbergh, Presenter: The 2015 Marian Chace Foundation Lecture
}

\author{
Julia Blair Rice ${ }^{1}$
}

Published online: 4 April 2016

(C) American Dance Therapy Association 2016

My name is Julia Blair Rice. I have been a dance movement therapist since 1979. I met Marylee in 1982 when I was hired to work at the hospital where she was working. I continue to work there, and Marylee is now an on-call therapist there. I have been lucky enough to do co-therapy and co-authorship with Marylee. She is my favorite ADTA conference roommate and dinner partner. Marylee Hardenbergh represents to me the archetype of a dance/movement therapist. She is a grant winning, award receiving, international choreographer. She has used dance on a grand site-specific scale as an environmental call to action, specifically around global water issues, and in a micro way to profoundly impact the lives of her clients. She is a Certified Movement Analyst who can brilliantly observe and comment on movement, and the reason we ask new employees to walk diagonally across the floor from high to low. She is a skilled clinician. The seasoned clinicians at my job say, "I channeled Marylee," when we are not sure about how to manage a difficult client or situation. This results in an intervention of disarming honesty and clarity supported by a deep sense of love and compassion, devoid of irritation.

Marylee started as a dance/movement therapist working with clients in the traditional manner. Her vision grew to encompass work as a choreographer in which she expanded her role as dance/movement therapist working with the Mississippi River, her audience, and her dancers. In this capacity, she has been able to transform people's relationships to their environment. Marylee is a pioneer of site-specific performance. These performances challenge the viewer to see themselves as part of their natural environment, and to foster a sense of collaboration and stewardship with that environment.

Marylee has been an integral part of my life for 32 years. What I remember of first meeting Marylee when I was a newly hired dance/movement therapist at Abbott

Julia Blair Rice

juliarice007@gmail.com

12729 29th Avenue Upper, Minneapolis, MN 55406, USA 
Northwestern Hospital is that by the end of this first encounter I had been encouraged to work on my registry application, invited to do an outpatient dance/movement therapy (DMT) group under her supervision, and graciously invited into the world of practicing, employed dance/movement therapists. Several days later, I received an invitation to her wedding in the mail. Marylee started as a colleague and co-therapist and has gone on to star as a co-author, bridesmaid and godmother. We worked together as co-therapists, leading an outpatient DMT group twice weekly for over 15 years. I have contentedly spent more waking time with Marylee than with anyone else in my life. Our co-therapy relationship deepened and influenced both our clinical skills and our friendship. Our collaboration extended to coauthoring a chapter on the treatment of eating disorders.

I have danced in two of her dances, standing 50 feet above the Mississippi River on a skeletal metal walkway above the lock and dam and with my daughter in a Mother's Day dance honoring the deep relationships of mothers and daughters through generations. My daughter has also danced for her on top of a building harnessed over the hydrology lab above the Mississippi River. My uncle has performed as a kayaker in Marylee's dance for the Jacob's Pillow Dance Festival on the Housatonic River. My mother stage managed Library Lights, a dance in the windows of the St. Paul Public Library. My husband has tested costume ideas by standing on top of his truck roof wrapped in tinfoil. To be part of Marylee's life is to be part of her artistic vision.

People don't talk much about manners anymore. What I mean when I use the word "manners" is an embodied compassion and awareness of the other in a relationship. In this context, Marylee is the best-mannered person I know. She was the first person to show up after the birth of my daughter; she is the first person to send a thank you or condolence note. She taught my husband how to massage me when I was pregnant and showed up to make dinner and play bride at the rehab center after my husband's spinal cord accident. She does all these things not because she doesn't have a million more pressing, rewarding, or creative things to do, but because she has the capacity to be deeply present in her friends' lives.

She is able to graciously and efficiently navigate the bureaucracy and hurdles that are part of getting permission to perform dances in untraditional places with her extraordinary amount of persistence and persuasion. When I read a CV like Marylee's, I snidely think to myself, this person cannot possibly be as good in person as they are on paper. Marylee is the rare sort of person who is spectacular and accomplished both in person and on paper. Her accomplishments include many awards and honors, including a Fulbright Scholarship, NEA fellowship, five McKnight Foundation Fellowships and a Soros Grant. Her CV lists 50 awards and fellowships. Her list of site-specific performances, opening and closing ceremonies, and movement choirs is long and growing. She is currently Artist in Residence at The Center for Global Environmental Education at Hamline University. Marylee has led movement choirs and directed site-specific dances at our conferences. It was during one of her movement choirs to honor newly registered dance/movement therapists that the tradition of the avenue of honor was created.

Her work on One River Mississippi, a multisite and simultaneous dance performed on the Mississippi River, served as an inspiration for Global Water 
Dances, performed simultaneously at sites across the world. The next Global Water Dances event is in June 2017; check the website to find out how you too can participate in this extraordinary experience (Global Water Dances, 2016). Marylee is the artistic director of both Global Water Dances and Global Site Performance. She has served on both local and national DMT boards. She has done site-specific choreography and movement choirs around the world. Many of you here have been part of her performances. The Marian Chace Foundation generously serves as the fiscal agent for the nonprofit she founded, Global Site Performance, (2015) whose vision is:

To create dances that exemplify great beauty, in vast spaces and in the hearts of communities, so that people connect more deeply with themselves, each other and the earth. To use the healing power of movement to foster within the participants a meaningful sense of place, of belonging and of joy. To promote the idea that we all inhabit one planet; to honor and respect the earth; and to raise awareness of environmental and social issues - and the need to care for the places we live, and for ourselves. (http://www.globalsiteperformance.org, "about", para 2, n.d)

Marylee graduated from Vassar College in 1970, received her master's degree in DMT from Goddard College in 1975, and earned her certificate in Laban Movement Analysis in 1975. Marylee and I had a client in one of our outpatient DMT groups. That client said to me she learned in our group how to love and be held so that she could love and hold her own children. Like that client, I have been blessed to feel the warmth of Marylee's love, and, like that client, I have been challenged and encouraged to become a better person, therapist and friend through my relationship with Marylee.

\section{Compliance with Ethical Standards}

Conflict of interest This author declares that there is no conflict of interest.

\section{References}

Global Water Dances. (2016). Global water dances: Dancing for safe water everywhere. http://globalwaterdances.org/

About Global Site Performance. (n.d). (2015). In Global site performance. http://www.globalsite performance.org/about/index.shtml

\section{Julia Blair Rice, MA, LICSW, BC-DMT}

has been a dance/movement therapist for 37 years. She works in a hospital based partial hospital program and in private practice. Her work with Marylee Hardenbergh has been some of the most rewarding in her career. Her other passion is Iyengar Yoga. 